ACTA MYCOLOGICA

Vol. 42 (2): 203-210

2007
Dedicated to Professor Alina Skirgietto

on the occasion of her ninety-fifth birthday

\title{
Genetic diversity of Heterobasidion spp. in Scots pine, Norway spruce and European silver fir stands
}

\author{
PIOTR ŁAKOMY ${ }^{1}$, ZBIGNIEW BRODA $^{2}$ and ANTONI WERNER ${ }^{3}$
}

\author{
${ }^{1}$ Department of Forest Pathology, The August Cieszkowski University of Agriculture \\ Wojska Polskiego 71c, PL-60-625 Poznań, plakomy@au.poznan.pl \\ ${ }^{2}$ Department of Genetics and Plant Breeding, The August Cieszkowski University of Agriculture \\ Wojska Polskiego 71c, PL-60-625 Poznań \\ ${ }^{3}$ Institute of Dendrobiology, Polish Academy of Sciences, Parkowa 5, PL-62-035 Kórnik
}

Ła ko my P., B rod a Z., We rne r A.: Genetic diversity of Heterobasidion spp. in Scots pine, Norway spruce and European silver fir stands. Acta Mycol. 42 (2):203-210, 2007.

Investigations of genetic diversity of Heterobasidion spp. in Scots pine, Norway spruce and European silver fir stands indicated that almost all of identified genets occurred in those stands were small occupied only a single stump. In some cases two, three or even four genets could effectively exist in an individual stump. Genetic similarity of $H$. annosum s.s. genets varied from $0 \%$ to $62 \%, H$. parviporum from $0 \%$ to $38 \%$ and $H$. abietinum from $0 \%$ to $55 \%$. The oldest and biggest genet was found in laying fir log and overgrew the wood for at least 14 years. This genet belonged to $H$. abietinum. The size of genets was related to thinning operation, spore dispersal, age of stand or competition in wood colonization.

Key words: Heterobasidion annosum sensu stricto, H. parviporum, H. abietinum, genets, pine, spruce, fir

\section{INTRODUCTION}

Root and butt rot caused by Heterobasidion spp. is the most important disease in forests. In Europe there were described three species of Heterobasidion - H. annosum (Fr.) Bref sensu stricto, Heterobasidion parviporum Niemelä and Korhonen, Heterobasidion abietinum Niemelä and Korhonen (Niemelä, Kor hon en 1998). In Poland the most economic losses causes H. annosum sensu stricto in Scots pine plantations growing on post-agricultural lands (Si r r o ta 1987, 1995; Mańk a 2005). Distribution of Heterobasidion species is related to the natural range of their main hosts. Heterobasidion annosum sensu stricto, which attack mainly Scots pine (Pinus sylvestris L.), occurs almost in whole Poland. Heterobasidion parviporum infected almost only Norway spruce (Picea abies (L.) Karst.) is noted in south and northeast part of Poland and Heterobasidion abietinum appeared on European silver fir (Abies alba Mill.) stumps or laying logs in south Poland. Those three species could 
infect more than 200 species also deciduous tree as birch, beach or oak (Webb, Alexander 1985; Łakomy et al. 2000; Lakomy, Werner 2003; Lakomy, Cieślak 2006).

Heterobasidion spp. is dispersed mainly by basidiospores, which colonise freshly cut stumps or wounds (Redfern and Stenlid 1998). In colonized stand pathogens could spread vegetatively by mycelium transfer via roots contacts between colonized and healthy tissue (Stenlid, Redfern 1998). The affected stumps or trees became the source of spore production. Appearance of new genets in stands is related to new spore infection, thinning operations and pathogen's frequency and in particular basidiocarps on stumps or trees. Almost sixty percent genets of Heterobasidion sp. identified in final cutting stands had infected only one tree (Piri et al. 1990; Vasiliauskas, Stenlid 1998). However, bigger genets were also described, which occurs in 10 or more trees (Stenlid 1985; Piri, Korhonen 2001). Small size of genets might be resulted by lacking of roots contact and impossibility of mycelium transfer among trees and stumps. It could also indicate that the genets are young or very old and are not able for spreading. The small size of genets could also indicate a high competition among genets in a single stump.

The aim of this study was $i$ ) to enter the investigations of distribution of Heterobasidion spp. genets in Scots pine, Norway spruce and European silver fir stands in Poland and ii) to investigate the genetic similarity of genets.

\section{MATERIALS AND METHODS}

Three stands were chosen to this study: 53-year-old Picea abies stand (Suwałki

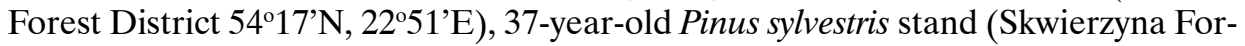
est District $5^{\circ} 33^{\prime} \mathrm{N}, 1^{\circ} 22^{\prime} \mathrm{E}$ ) and 180-year-old Abies alba stand (Siemianice Experimental Forest of August Cieszkowski Agricultural University in Poznań, 5101'N, $\left.18^{\circ} 05^{\prime} \mathrm{E}\right)$. Norway spruce and Scots pine stands were growing as a first generation on post-arable soil. In fir stand two groups of stumps were chosen for this study (7 stumps and laying log and 5 stumps). The two groups were remote each other about $250 \mathrm{~m}$. In each stand, stumps were investigated for presence of decay or Heterobasidion sp. basidiocarps. Wood from stumps was collected.

In laboratory the mycelium of Heterobasidion sp. were isolated from wood samples. The genets were identified with the aid of somatic incompatibility test (S te n lid 1985). Cultures were pairing in all possible combinations on 1.5\% Malt Extract Agar (Merck, Germany). After 2-3 weeks pairings were marked to presence the demarcation line indicating different genets. Isolates representatives of each genet were identified to Heterobasidion species with the compatibility test (Korhonen 1978).

Genetic analysis. RAPD analysis were carried out using DNA, extracted as by Thompson and Henry (1995) from genotypes of $H$. annosum ss., H. parviporum and $H$. abietinum. DNA of each genotype was extracted from $10 \mathrm{~mm}^{2}$ mycelium, soaked for $15 \mathrm{~min}$ at $95^{\circ} \mathrm{C}$ in $120 \mu \mathrm{l}$ of TPS buffer.

PCR reactions $(12,5 \mu \mathrm{l})$ contained $10 \mathrm{ng}$ of genomic DNA, 0,94 u Taq polymerase, 1.25 pmol of primer, $2 \mathrm{mM}$ of dNTP, $1.25 \mu \mathrm{l}$ of BSA, $25 \mathrm{mM} \mathrm{MgCl}_{2}$ and Tris-HCL. Six oligonucleotide primers (10 bases long) were used in each PCR amplification. 
The cycling was performed as follows: $94^{\circ} \mathrm{C} / 60 \mathrm{~s}$ followed by 10 cycles of amplification $\left(94^{\circ} \mathrm{C} / 5 \mathrm{~s}, 37^{\circ} \mathrm{C} / 30 \mathrm{~s}, 72^{\circ} \mathrm{C} / 30 \mathrm{~s}\right)$ and the next 35 cycles $\left(94^{\circ} \mathrm{C} / 5 \mathrm{~s}, 37^{\circ} \mathrm{C} / 30 \mathrm{~s}\right.$, $\left.72^{\circ} \mathrm{C} / 30 \mathrm{~s}\right)$.

Amplification products were resolved by electrophoresis on gel consisting of $1,5 \%$ agarose and TBE buffer with ethidium bromide $10 \mu \mathrm{l} / 100 \mathrm{ml}$.

Genetic similarities among genotypes were estimated using Nei's equation ( $\mathrm{Ne}$ i and Li 1979).

\section{RESULTS}

Scots pine stand. Among analysed 34 stumps, 23 were colonized by Heterobasidion annosum s. s. In $80 \%$ stumps the pathogen was also present in root systems. On the base of somatic incompatibility test this area was colonized by 32 genets of $H$. annosum sensu stricto. Genets were very small. One genet occupied mainly only one stump. In five stumps there were found two different genets and in one stump - three.

Genetic similarity of genets varied from $0 \%$ to $62 \%$. (fig.1). The genetic diversity of the $H$. annosum sensu stricto population was high. Only in 5\% cases the genetic similarity between two genotypes was relatively high $(40 \%-62 \%)$ and in $1,5 \%$ was low $(5 \%)$. In $24 \%$ cases the compared genets were genetically different. Genetic similarity of genets occupying the same stump varied from $0 \%-54 \%$. In stump where three genets colonized wood similarity among genets was $10 \%, 18 \%$ and $40 \%$.

Norway spruce stand. In this stand 21 stumps were located in the plot. 15 stumps (71\%) were colonized by Heterobasidion parviporum. 24 genets colonized this area. Genets were small and occupied only one stump at least. In two cases, four different

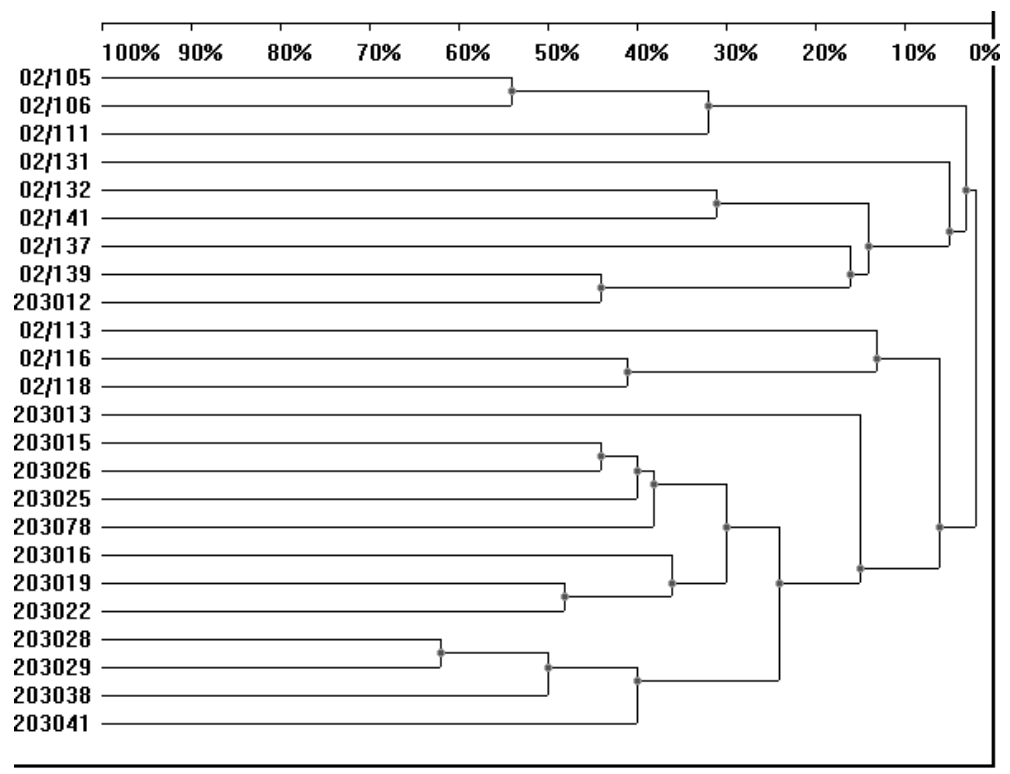

Fig.1. Dendrogram of similarity among genotypes of $H$. annosum sensu stricto. 


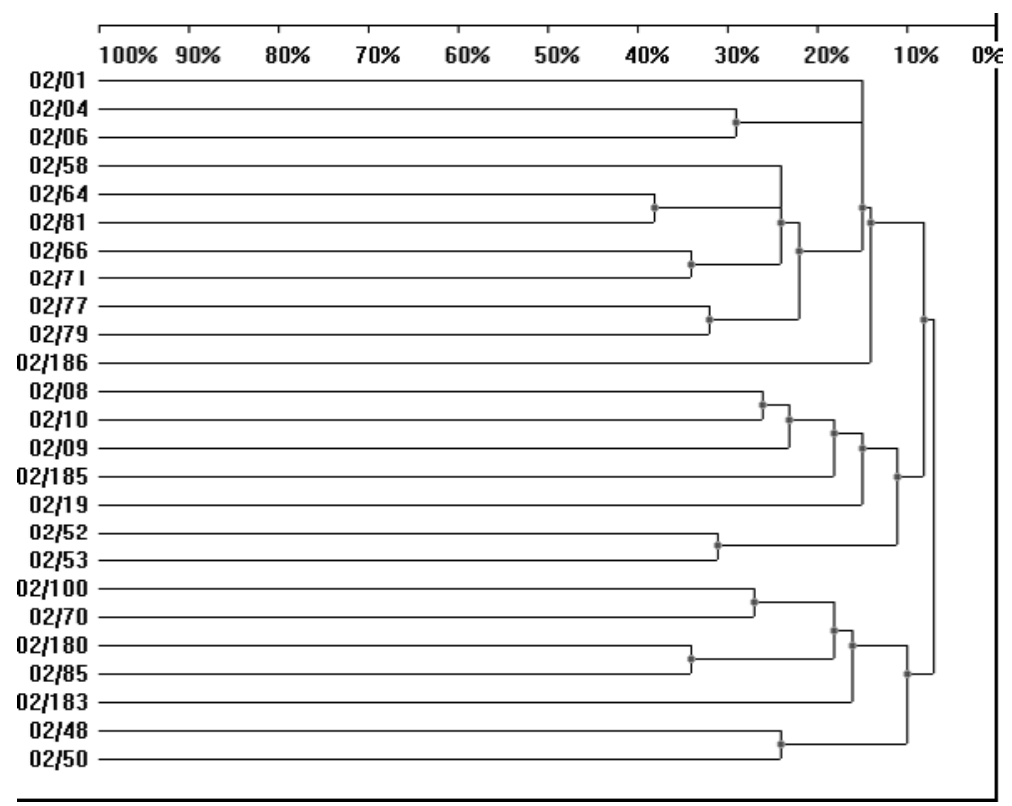

Fig.2. Dendrogram of similarity among genotypes of $H$. parviporum.

genets were found in stump, but in five cases 2 different genets colonized one stump.

Genetic similarity of genets varied from $0 \%$ to $38 \%$ (Fig.2). In $4 \%$ cases genetic similarity between two genets varied from $30 \%-38 \%$. The lowest genetic similarity between genets was $9 \%$. Also in $9 \%$ genets were totally different. Similarity of genets that occupied the same stump varied from $4 \%$ to $35 \%$. In stumps colonized by 4 genets, their similarity varied from $16 \%$ to $35 \%$. There were no genetically different genets in one stump.

European silver fir stand. On the first plot Heterobasidion abietinum colonized laying log and only two stumps (29\%) and on the second the pathogen occurred in

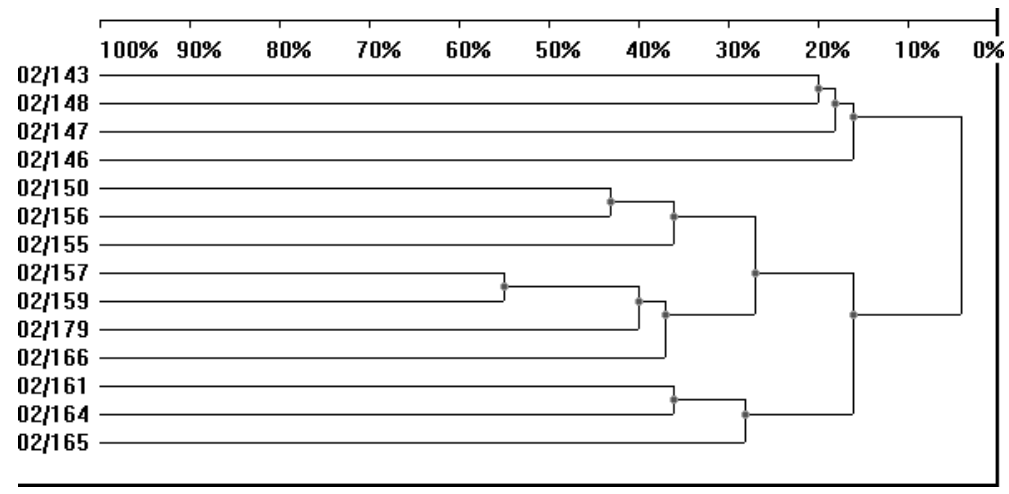

Fig.3. Dendrogram of similarity among genotypes of $H$. abietinum. 
3 tumps (60\%). On the base of somatic incompatibility stumps were colonized by 14 genets ( 7 in each plot). In the laying log three genets were localized. Two were small and occupied about $50 \mathrm{~cm}$ of stem. The third genet colonized wood on distance $7 \mathrm{~m}$ of stem. Three stumps were colonized by two genets in each stump and in one stump grew four genets of $H$. abietinum. One stump was whole colonized by one genet.

Genetic similarity of genets varied from $0 \%$ to $55 \%$ (Fig. 3). The highest similarity $(40 \%-55 \%)$ was found in $5 \%$ of compared genets. In $13 \%$ cases the genets were genetically different. Similarity among genets colonized the same stump varied from $0,16 \%$ to $36 \%$.

\section{DISCUSSION}

In this study all genets localized in Norway spruce and Scots pine stands were small. The most probable infection mode was done by basidiospores after thinning. Each stand was thinned at least three times (precommercial and commercial thinning). In Scots pine stands only after the last thinning all stumps were treated against Heterobasidion annosum s.s. with Phlebiopsis gigantea (Fr.: Fr.) Jülich., while stumps in the Norway spruce stand had never been treated with biopreparation. There were good conditions for stump infection for a long time. Both pine and spruce stand grew as a first generation of forest in post-arable soil. So the small size of genets might be resulted of relatively short time of Heterobasidion spp. existence in those stands. Although the vegetative spread of pathogens mycelia should be considered, even if genets were restricted to single stump.

Completely different situation was observed in $A$. alba stand. Lack of stumps in this stand was connected with age of trees and very limited treatment. Only dead or damaged by wind trees had been removed for last years. So almost all stumps were decayed. Those genets probably were older than in pine and spruce stands. Probably there were two reasons of small genet size - age of stumps and distance among stumps $(2-15 \mathrm{~m})$. The root system around stumps had been decaying and diminishing for years and possible vegetative spread was also difficult. In addition size of genets colonizing the root system could also shrink. The proof of this idea is the size of genet in laying log. The stem was colonized after felling, because butt of stem was not colonized by $H$. abietinum. The biggest genet, which has been found, occupied wood on distance $7 \mathrm{~m}$. Considered the speed of mycelium growth in dead wood (50 $\mathrm{cm}$ per year) this genet exists for at least 14 years.

This observation improves earlier findings (Kowalski, Łakomy 1998) that root pathogen was able to infect the higher parts of stem after tree felling. Probably it was in connection with dead wood.

Kalio (1970) found that Heterobasidion annosum spores could spread even up to $500 \mathrm{~km}$. The high genetic diversity of pathogen's genets and occurrence of many different or weakly similar genets could be explained by high pressure of spores from vicinity stands. This situation was also caused by lack of stump treatment against Heterobasidion sp. after thinning. The age of Norway spruce and Scots pine stands influenced the size of genets. At the beginning of stands colonization the vegetative spread via root systems must be limited.

The typical life span of Heterobasidion spp. mycelium in roots is still not known. However on the base of the average rapid mycelial growth in roots the largest area 
occupied by a single genet was estimated on $50 \mathrm{~m}$ in diameter and the age of this genet would not be much more than 100 years (Stenlid and Redfern 1998). In investigated stands genets were very young and the oldest one found in fir stand has less than 20 years.

In coniferous stands a lot of $H$. annosum genotypes could exist in disease stand or gap (Chase, Urlich 1983; Garbelot to 1996; Harrington et al. 1998). Stenlid et al. (1998) found that size of genotypes could be large and one genotype could colonize even 15 trees. However Piri et al. (1990) and Piri (1996) indicated that genotypes in investigated stands colonized only 3 trees. Bodles et al. (2005) described genets in Sitka spruce stand, which had been never thinned before. They found that maximum number of trees affected by one genet was 6 and genet size varied from those occupied single tree to $22,5 \mathrm{~m}$ in length. The age of the largest genets, which were $22,5 \mathrm{~m}$ in length, $17,5 \mathrm{~m}$ and $9 \mathrm{~m}$, they estimate on 45,35 and 18 years, respectively. Swe djemark and Stenlid (1993) suggested that even if tree was colonized by two or more genets only one may eventually dominate in a single host tree and Woodward et al. (2005) partially supported that hypothesis. Lakomy, Boroda and Werner (2005, unpublished) observed that in some cases only one genet from two or more, which colonized the same stump characterize of highest growth rate in wood of living tree. This situation was noted for $H$. annosum ss., $H$. parviporum and $H$. abietinum genets existing in one stump (pine, spruce or fir). But at the other hand they also observed two dominant genets among three or four from the same stump. It might be result of competition between genets in wood colonization. However they also find no differences in wood colonization among two or three genets from a single spruce or even small pine stump.

Previous works indicated on existing variation in virulence between Heterobasidion species and also between isolates inside each species (Werner 1987, 1991; Stenlid, Swedjemark 1988; Swedjemark, Stenlid 1993; Werner, Łakomy 2001, 2002). Łakomy et al. (2005) suggested that damages might be related with number of active genets of Heterobasidion in stand. They showed that the variation of virulence among isolates belonged to the same species might be important for disease progress in stands. In their experiments the highest mortality caused both genets of Heterobasidion annosum genetically different and also in some degree similarity $(30 \%)$.

Those three populations of $H$. annosum ss., $H$. parviporum and $H$. abietinum characterized of high genetic diversity. In pine and spruce stands this situation was resulted the high success in Heterobasidion spp. colonization of fresh stumps appearing after routine thinning operation. Those genets are young because both stands growth as a first generation on post agricultural soil. Moreover in spruce stands forest service had never treated stump s against $H$. parviporum and in pine stand this operation had been done too late - during last commercial thinning. At least twice stumps after precommercial thinning were open to spore infection. Different situation observed in fir stand was connected with trees' age (180-years-old). Some genets of $H$. abietinum must be old especially those which were present in old decayed stumps. In addition law number of stumps in stand was an important barrier to H. abietinum distribution. 
Acknowledgements: The authors are grateful to Dr Kari Korhonen and Prof. Paolo Capretti for providing pure cultures of Heterobasidion spp. annosum and Anna Ratajczak, Arleta Świetlik, Anna Błaszkowiak, Leokadia Torz, Ewa Nowak for their assistance in this project. The Polish Committee for Scientific Research financially supported this study, grant no. 3P06L 05422.

\section{REFERENCES}

Bodles W. J. A., Beckett L., Zamponi S., Woodward S., Keča N., Capretti P. 2005. Heterobasidion annosum population recruitment and spread in a severely infected Sitka spruce stand in north east Scotland. (In:) M. Mańka and P. Łakomy (eds). Root and Butt Rots of Forest Trees. Proceedings of IUFRO Working Party 7.02.01. 11 $1^{\text {th }}$ International Conference on Root and Butt Rots. Poznań-Białowieża, Poland. 16-22 Aug. 2004: 83-93.

Chase T. E., U11rich R. C. 1983. Sexuality, distribution and dispersal of Heterobasidion annosum in pine plantations of Vermont. Mycologia 74: 825-831.

Garbole t t o M. 1996. The genetic structure of populations of Heterobasidion annosum (Fr.) Bref. from the global to local scale: implications for the biology, the epidemiology and the evolution of a forest pathogen. Ph. D Thesis, University of California, Berkeley.

Harrington T. C., Rizzo D. M., Descenzo R. A., Steimel J. 1998. Genetic relationships among clones of Heterobasidion annosum in pine forest. (In:) C. De la to u r, J. J. Guilla u m in, B. Lu ngescarmant, B. Marcais (eds). Root and Butt Rots of Forest Trees (9th International Conference on Root and Butt Rots), INRA Editions (France), Les Colloques n ${ }^{\circ}$ 89: 159-170.

Kalli o T. 1970. Aerial distribution of the root-rot fungus Fomes annosus (Fr.) Cooke in Finland. Acta Forest Fenn. 107.

Kor h on en K. 1978: Intersterility groups of Heterobasidion annosum. Communicationes Instituti Forestalis Fenniae 94(6): 25pp

Kowalski T., Łak k my P., 1998. A new record of Heterobasidion annosum (Fr.) Bref. F group occurrence, in Poland in connection with interesting mycological findings. Phytopathologia Polonica XV: 49-56.

Łakomy P., Cieślak R. 2006. Huba korzeni na bukach - ciekawostka czy problem? Las Polski 3: $22-23$.

Łak omy P., Werner A. 2003. Distribution of Heterobasidion annosum intersterility groups in Poland. For. Path. 33: 105-112.

Łakomy P., Kowalski T., We rner A. 2000. Preliminary report of Heterobasidion annosum intersterility groups in Poland. Acta Mycologica 35: 303-309.

Łak omy P., Werner A., Broda Z. 2005. Pathogenicity of Heterobasidion annosum S group clones to Norway spruce seedlings. (In:) M. Mańka and P. Łakomy (eds). Root and Butt Rots of Forest Trees. Proceedings of IUFRO Working Party 7.02.01. $11^{\text {th }}$ International Conference on Root and Butt Rots. Poznań-Białowieża, Poland. 16-22 Aug. 2004: 94-100.

Mań ka K. 2005: Fitopatologia Leśna. PWRiL Warszawa, 368 pp.

Ne i M., Li W. H. 1979. Mathematical model for studying genetic variation in terms of restriction endonucleases. Proc. Natl. Acad. Sci. 79: 5269-5273.

Niemelä T., Korhonen K. 1998. Taxonomy of the genus Heterobasidion. (In:) S. Woodward, J.S tenlid, R. Karjala ine n, A. Hüt term a n (eds). Heterobasidion annosum: Biology, Ecology, Impact and Control. C.A.B. International: 27-33.

Piri T. 1996. The spreading of the S type of Heterobasidion annosum from Norway spruce stumps to the subsequent tree stand. Eur. J. For. Path. 26: 193-204.

Piri T., Kor hon en K. 2001. Infection of advanced regeneration of Norway spruce by Heterobasidion parviporum. Canadian Journal Forest Research 31: 937-942.

Piri T., Korh on en K., S a ir a n e n A. 1990. Occurrence of Heterobasidion annosum in pure and mixed stands in southern Finland. Scand. J. For. Res. 5: 113-125.

Redfern D. B., Stenlid J. 1998. Spore dispersal and infection. (In:) S. Woodward, J. Stenlid, R. Karjala in en, A. Hütterman (eds). Heterobasidion annosum: Biology, Ecology, Impact and Control. C.A.B. International: 105-124.

Sierota Z. 1987. Czynniki sprzyjające występowaniu huby korzeni w drzewostanach sosnowych na gruntach porolnych (Factors favouring the occurrence of Fomes annosus in pine stands on former agricultural grounds). Sylwan 131 (11-12): 69-82. 
Si e r o t a Z. 1995. Rola grzyba Phlebiopsis gigantea (Fr.: Fr.) Jülich w ograniczaniu huby korzeni w drzewostanach sosny zwyczajnej (Pinus sylvestris L.) na gruntach porolnych. Prace Instytutu Badawczego Leśnictwa 810: $180 \mathrm{pp}$.

Stenlid J. 1985. Population structure of Heterobasidion annosum as determined by somatic incompatibility, sexual incompatibility, and isoenzyme patterns. Can. J. Bot. 63: 2268-2273.

St en lid J., Sw e d j e m a rk G. 1988. Differential growth of S- and P-isolates of Heterobasidion annosum in Picea abies and Pinus sylvestris. Transaction of the British Mycological Society 90(2): 209-213.

Stenlid J., Redfern D. B. 1998. Spread within the tree and stand. (In:) S. Woodward, J. Stenlid, R. Karjala in en, A. Hüt te r m an (eds). Heterobasidion annosum: Biology, Ecology, Impact and Control. C.A.B. International: $125-141$.

Stenlid J., Kammiovirta K., Karjalainen R., Karlsson J-O., Korhonen K., Solheim H., Thomsen I. 1998. Genetic variation among European S- and P-group populations of Heterobasidion annosum assessed by arbitrary priming. (In:) C. Delat ou r, J. J. Guilla u min, B. Lungescarmant, B. Marcais (eds): Root and Butt Rots of Forest Trees (9th International Conference on Root and Butt Rots), INRA Editions (France), Les Colloques $n^{\mathrm{O}}$ 89: 75-84.

Swe dje mark G., Stenlid J. 1993. Population dynamics of the root rot fungus Heterobasidion annosum following thinning of Picea abies. Oikos 66: 247-254.

Thompson D., Henry R. 1995. Single-step protocol for preparation of plant tissue for analysis by PCR. Bioo. Techniques 19: 394-400.

Vasiliauskas R., Stenlid J. 1998. Spread of S and P group isolates of Heterobasidion annosum within and among Picea abies trees in central Lithuania. Can. J. For. Res. 28: 961-966.

We eb R. S., Alex ander S. A. 1985. An updated host index for Heterobasidion annosum. Virginia Polytechnic Inst. State University Inform Series No. 85-2: 27pp (Abstr. In Rev. Plant Pathol. 67: 63. 1988).

Werner A. 1987. Responses in vitro grown pine seedlings to infection by four strains of Heterobasidion annosum. Eur. J. For. Path. 17: 93-101.

Werner A. 1991. Resistance to Heterobasidion annosum of first and second generation Scots pine trees from an old disease centre. Arboretum Kórnickie Rocznik 36: 113-126.

Werner A., Ła k o m y P. 2001. Intraspecific variation in Heterobasidion annosum (Fr.) Bref. for mortality rate on Pinus sylvestris L. and Picea abies (L.) Karst. seedlings grown in pure culture. Mycologia 94 (5): 855-860.

Werner, A., Łakomy P. 2002. Host specialization of IS-group isolates of Heterobasidion annosum to Scots pine, Norway spruce and common fir in field inoculation experiments. Dendrobiology 47: 59-68.

Woodward S., Har a mburu E., Johnston D. H. 2005. Heterobasidion annosum in a severly affected Norway spruce stand following chemical thinning. (In:) M. M án k and P. Ł a ko my (eds). Root and Butt Rots of Forest Trees. Proceedings of IUFRO Working Party 7.02.01. 11 $1^{\text {th }}$ International Conference on Root and Butt Rots. Poznań-Białowieża, Poland. 16-22 Aug. 2004: 363-371.

\section{Zróżnicowanie genetyczne grzybów rodzaju Heterobasidion w drzewostanach: sosnowym, świerkowym i jodłowym}

\section{Streszczenie}

Badania nad zróżnicowaniem genetycznym gatunków rodzaju Heterobasidion w drzewostanach sosnowym, świerkowym i jodłowym wskazały, że niemalże wszystkie genotypy występujące w badanych drzewostanach były małe i zasiedlały co najwyżej jeden pniak. W kilku przypadkach stwierdzono występowanie dwóch, trzech, a nawet czterech genotypów w jednym pniaku. Podobieństwo genetyczne genotypów $H$. annosum s. s. wynosiło od $0 \%$ do $62 \%, H$. parviporum od $0 \%$ do $38 \%$, a H. abietinum od $0 \%$ do $55 \%$. Najstarszy i największy genotyp stwierdzono w leżącej kłodzie jodłowej, której drewno przerastał, przez co najmniej 14 lat. Ten genotyp należał do H. abietinum. Rozmiar genotypów był związany z intensywnością cięć pielęgnacyjnych w drzewostanach, rozprzestrzenianiem zarodników, wiekiem drzewostanów oraz konkurencją w zasiedlaniu drewna pomiędzy genotypami. 